\title{
Germination of Ocotea pulchella (Nees) Mez (Lauraceae) seeds in laboratory and natural restinga environment conditions
}

\author{
Pires, LA. ${ }^{\mathrm{a} *}$, Cardoso, VJM. ${ }^{\mathrm{a}}, \mathrm{Joly}, \mathrm{CA} .^{\mathrm{b}}$ and Rodrigues, $R$. $^{\mathrm{c}}$

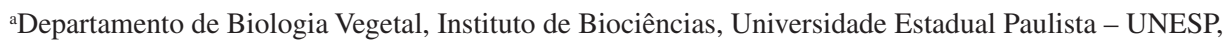 \\ Av. 24A, 1515, CEP 13506-900, Rio Claro, SP, Brazil \\ ${ }^{\text {b}}$ Departamento de Botânica, Instituto de Biociências - IB, Universidade Estadual de Campinas - UNICAMP, \\ CP 6109, CEP 13083-970, Campinas, SP, Brazil \\ 'Departamento de Ciências Biológicas, Escola Superior de Agricultura “Luiz de Queiroz" - ESALQ, \\ Universidade de São Paulo - USP, \\ CP 9, CEP 13418-900, Piracicaba, SP, Brazil \\ *e-mail: luapires@hotmail.com
}

Received January 22, 2008 - Accepted April 1, 2008 - Distributed August 31, 2009

(With 5 figures)

\begin{abstract}
The germination response of Ocotea pulchella (Nees) Mez seeds to light, temperature, water level and pulp presence is introduced. The laboratory assays were carried out in germination chambers and thermal-gradient apparatus, whereas the field assays were performed in environments with distinct light, temperature and soil moisture conditions within a permanent parcel of Restinga forest of the Parque Estadual da Ilha do Cardoso, Cananéia, São Paulo. The seeds do not exhibit dormancy, they are non photoblastic, and a loss of viability in dry stored seeds can be related to a decrease in water content of the seed. The presence of the pulp and the flooded substratum influenced negatively the germination of $O$. pulchella seeds tested in the laboratory. Otherwise, light and temperature probably are not limiting factors of the germination of $O$. pulchella seeds in the natural environment of Restinga. The optimum temperature range for germination of Ocotea pulchella seeds was 20 to $32{ }^{\circ} \mathrm{C}$, the minimum or base temperature estimated was $11^{\circ} \mathrm{C}$ and the maximum ranged between 33 and $42^{\circ} \mathrm{C}$. The isotherms exhibited a sigmoidal pattern well described by the Weibull model in the sub-optimal temperature range. The germinability of $O$. pulchella seeds in the understorey, both in wet and dry soil, was higher than in gaps. Germination was not affected by fluctuations in soil moisture content in the understorey environment, whereas in gaps, germination was higher in wet soils. Thus, the germination of this species involves the interaction of two or more factors and it cannot be explained by a single factor.
\end{abstract}

Keywords: Ocotea pulchella, germination, Restinga forest, temperature, light

\section{Germinação de sementes de Ocotea pulchella (Nees) Mez (Lauraceae) em laboratório e em ambiente natural de Restinga}

\begin{abstract}
Resumo
É apresentada a germinação de sementes de Ocotea pulchella (Nees) Mez em resposta a: luz, temperatura, nível de água e presença de polpa. Os ensaios de laboratório foram realizados em câmaras de germinação e em equipamento de gradiente térmico, e os de campo, em ambientes com diferentes condições de luz, temperatura e umidade no solo, em uma parcela permanente em floresta de Restinga no Parque Estadual da Ilha do Cardoso, Cananéia, São Paulo. As sementes de Ocotea pulchella não possuem dormência, são afotoblásticas, e a perda de viabilidade de sementes armazenadas a seco pode estar relacionada a um decréscimo no seu conteúdo de água. A presença da polpa e o substrato alagado afetaram negativamente a germinação de $O$. pulchella em laboratório. Luz e temperatura não são provavelmente fatores limitantes da germinação de sementes de $O$. pulchella no ambiente natural da Restinga. A faixa térmica ótima de germinação foi de 20 a $32{ }^{\circ} \mathrm{C}$; a temperatura mínima ou base foi estimada em $11{ }^{\circ} \mathrm{C}$; e a temperatura máxima variou de 33 a $42{ }^{\circ} \mathrm{C}$. As isotermas na faixa térmica infraótima exibem padrão sigmoidal e foram bem descritas pelo modelo de Weibull. A germinabilidade no sub-bosque, tanto em solo com maior umidade como em solo mais seco, foi maior do que em clareira. No sub-bosque não houve diferença na germinação em relação a variações na umidade do solo, ao passo que em clareiras a germinabilidade foi maior em solo mais úmido. Assim, a germinação dessa espécie deve ser função da interação de fatores, não podendo ser explicada apenas por um único fator.
\end{abstract}

Palavras-chave: Ocotea pulchella, germinação, Restinga, temperatura, luz. 


\section{Introduction}

Restinga forests occur in sandy seashore plains, composed of a range of structurally distinct plant communities and mainly related to soil characteristics such as water saturation, water bed depth, organic matter content, age and structure, as well as to the placement of the communities, e.g., the distance from seashore or mangrove (Silva, 1988).

Lowland tropical forest trees are in general derived from seeds. Thus, the knowledge of the effects of different environmental factors on the seed germination is essential for knowing the species distribution and the processes occurring at community level such as seedling establishment, plant succession and natural regeneration (Raich and Khoon, 1990; Vázquez-Yanes and OrozcoSegovia, 1990). Many studies have been carried out showing that the species composition of distinct vegetation physiognomies from tropical forests is related to the specific requirements and adaptations of both the germination process and seedling development to different light, temperature, moisture and soil nutrients conditions in the range of forest microenvironments, including canopy gaps and flooded areas (Whitmore, 1978; Denslow, 1980; Joly, 1991).

Temperature is a very important factor controlling seed germination, affecting both the rate and final percentage of germination. Within a given range, only the germination rate (the reciprocal of the time taken for germination) is affected by temperature and such germination rate dependency on temperature may be one of the most important factors controlling the emergence timing in the field, thus influencing the probability of seedling establishment (Washitani, 1985). Most seeds exhibit minimum $\left(\mathrm{T}_{\mathrm{b}}\right)$, optimum $\left(\mathrm{T}_{\mathrm{opt}}\right)$ and maximum $\left(\mathrm{T}_{\max }\right)$ temperatures for germination. In the sub-optimum temperature range, a thermal time approach can be used to characterize the distribution of the time to germination at different sub optimal temperatures, according to a model proposed by Garcia-Huidobro et al. (1982). For seeds, the thermal time represents the progress toward germination and it can give a good estimate of the time to emergence for specific crops. According to the model, in the sub-optimum range the germination rate increases linearly with the temperature and the variation in the time to germination is due to the seeds having different thermal time requirements. At supra-optimal temperatures, however, both the germination rate and germinability declines as temperature increases, and the variation of $\mathrm{T}_{\text {max }}$ accounts for the differences in the rates of germination, while the thermal time to radicle protrusion is a constant for all seeds (Bradford, 1995).

Although some studies have focused on ecophysiological aspects of Restinga species (Scarano et al., 1997; Pinheiro and Borghetti, 2003), much work is still necessary - particularly for those related to the initial plant development stages - to understand forest dynamics and contribute to recovery and conservation actions of the Restinga biome. Ocotea pulchella (Nees) Mez (Lauraceae) is a tree growing up 4 to $30 \mathrm{~m}$ in height; zoochoric; occurring frequently in Restinga forest; with high IVI (importance value index) in non-flooded forests in the south littoral of São Paulo State and the north of Paraná State (Carrasco, 2003; Sugiyama, 2003; Silva and Britez, 2005). O. pulchella is also widely distributed in the seasonal forests of Espírito Santo, Minas Gerais, Mato Grosso do Sul and the south of Brazil (Lorenzi, 1992), as well as in gallery forests and the Cerrado of São Paulo state (Gomes et al., 2004; Teixeira and Rodrigues, 2006). The species is indicated for reforestation in São Paulo state (São Paulo, 2001) and has been classified as anthropic pioneer (Salimon and Negrelle, 2001), and late secondary (São Paulo, 2001).

The project is included in the major program "Diversity, dynamics and forest conservation in São Paulo state: 40 ha of permanent plots", of the FAPESP Biota Programme. In this programme, permanent plots of 10.24 ha each were located in different forest stands, including a plot in a Restinga forest of "Ilha do Cardoso", São Paulo state, within which $O$. pulchella contributes to $3.5 \%$ of the trees $\geq 4.8 \mathrm{~cm}$ DAP (Oliveira et al., 2006). This paper presents the results of the assays on the germination response of $O$. pulchella seeds to light, temperature and water level, both in the natural environment and controlled laboratory conditions, and discusses the role played by those factors on the germination of the species in the Restinga environment.

\section{Material and Methods}

Ocotea pulchella seeds were collected in October 2003 in a Restinga forest of the "Parque Estadual da Ilha do Cardoso", Cananéia, and Ilha Comprida, São Paulo state, from each of at least six mature plants. The seeds were cleaned (pulp removal) by hand under tap water with the aid of a sieve. Newly collected seeds were used in the laboratory assays, whereas seeds stored for nearly ten days were used in the field germination assays. The seed water content (fresh weight basis) was determined from three samples of 20 seeds each, according to Silva (1988). For imbibition time-course, five samples of 20 seeds each were taken at random from the batch, weighed and immersed in distilled water at $25{ }^{\circ} \mathrm{C}$; then the samples were periodically removed from water, blotted on filter paper, weighed and returned to water.

\subsection{Laboratory assays}

The assays testing the effect of light conditions were performed in $11.5 \times 11.5 \times 3 \mathrm{~cm}$ germination boxes (gerbox) filled with vermiculite moistened with distilled water. For the darkness treatments, black germination boxes were used. The assays were kept in growth cabinets at $25 \pm 1{ }^{\circ} \mathrm{C}$. Each experiment was carried out with five replicates of 20 seeds per replicate. White light was obtained with "day-light" fluorescent lamps (irradiance of $29.3 \mu \mathrm{mol} . \mathrm{m}^{-2} / \mathrm{s}$ at gerbox level), and far-red light (ir- 
radiance of $5.36 \mu \mathrm{mol} . \mathrm{m}^{-2} / \mathrm{s} . \mathrm{nm}^{-1}$ ) was obtained with a filter composed of a layer of red acrylic and a layer of blue acrylic (maximum transmission at $730 \mathrm{~nm}$ ) under a $40 \mathrm{~W}$ tungsten bulb. The germination boxes were covered with nylon screen (sombrite ${ }^{\circledR} 50 \%$ ) for lower irradiances treatments. The germination (radicle protrusion through the seed coat) in both darkness and far red light treatments was recorded under green safety light (Amaral-Baroli and Takaki, 2001).

In the flooding experiment, a volume of water was added to the substrate, just enough to cover the seeds. An assay was carried out to compare the germination of intact fruits and naked (pericarp free) seeds. Both the experiments were carried out in germinators at $25^{\circ} \mathrm{C}$ under white light.

The temperature dependence of the germination was assayed in a temperature gradient block based on methodology described by Labouriau and Agudo (1987), over the temperature range of $16-40{ }^{\circ} \mathrm{C}$. The temperatures were measured with PT100 sensors connected to an electronic thermometer JK model SK 010. The seeds were germinated in plastic trays lined with strips of qualitative filter paper kept saturated with distilled water, and the trays were put inside glass assay tubes $(250 \times 25 \mathrm{~mm})$, closed with inox stoppers. Five tubes with 20 seeds each were used per treatment. In all the thermal treatments, the seeds were maintained in darkness throughout, except when the tubes were removed from the block for germination counts.

Germinability was measured by the final germination percentages of the pooled samples. The average germination rate was calculated according to Labouriau and Agudo (1987) for the assays testing the effect of light regimes and the effect of flooding on germination. For the experiments focusing on the effect of temperature on the germination of Ocotea pulchella, the germination rate was computed as the reciprocal of the time (days) to radicle emergence of an arbitrary percentage or fraction $\mathrm{g}(\mathrm{g}=5,10,20,30,40$ and 50\%), estimated from the germination time courses fitted by the Weibull function (Dumur et al., 1990). Germination time courses at the infra-optimum temperatures were normalised on a thermal time scale (Garcia-Huidobro et al., 1982) from the parameter $\mathrm{T}_{\mathrm{b}}$ (base temperature) identified according to the model: $\operatorname{probit}(\mathrm{g})=\left\{\log \left[\left(\mathrm{T}-\mathrm{T}_{\mathrm{b}}\right) \mathrm{t}_{\mathrm{g}}\right]-\log \theta \mathrm{T}_{(50)}\right\} /$ $\sigma \theta_{\mathrm{T}}$, where probit(g) is the probit transformation of percentage $\mathrm{g} ; \mathrm{t}_{\mathrm{g}}$ is the time to germination of $\mathrm{g}$ per cent; $\theta \mathrm{T}_{(50)}$ or $\mu$ is the median thermal time to germination and; $\sigma \theta_{\mathrm{T}}$ is the standard deviation (the inverse of the slope of the probit regression line). The $\mathrm{T}_{\mathrm{b}}$ value was obtained by combining the data from a range of temperatures and varying the value of $\mathrm{T}_{\mathrm{b}}$ until the best fit is obtained (Bradford, 1995). For the temperatures of 32 and $35^{\circ} \mathrm{C}$, it was assumed that thermal time did not vary within the population and that variation in $\mathrm{T}_{\max }$ accounts for the variation in germination time of Ocotea pulchella. Such variation in $\mathrm{T}_{\max }$ was described by the model: $\operatorname{probit}(\mathrm{g})=$ $\mathrm{a}+\left[\left(\mathrm{T}+\theta / \mathrm{t}_{\mathrm{g}}\right) / \sigma_{\mathrm{Tmax}}\right]$, where $\mathrm{a}$ is an intercept constant; $\theta$ is the thermal time and $\sigma_{\operatorname{Tmax}}$ is the standard deviation of the frequency distribution of $\mathrm{T}_{\max }$ within the sample (Ellis et al., 1986). Thus, the thermal time value was obtained by plotting probit $(\mathrm{g})$ against $\left[\left(\mathrm{T}+\theta / \mathrm{t}_{\mathrm{g}}\right)\right]$ and varying the value of $\theta$ until the highest coefficient of determination $\left(\mathrm{r}^{2}\right)$ is attained.

Both the germinabilities and average germination rate were tested for homogeneity of the variances (Bartlett test) and submitted to Anova if the variances were homogeneous, otherwise non parametric statistics (e.g. Kruskall-Wallis or Mann-Whitney tests) were used.

\subsection{Field assays}

The assays were carried out in a permanent plot of 10.24 ha divided into $20 \times 20 \mathrm{~m}$ sub-parcels, located in a Restinga stand of "Ilha do Cardoso", São Paulo state $\left(24.93^{\circ} \mathrm{S}\right.$ e $\left.47.95^{\circ} \mathrm{W}\right)$. The climate in the region has been classified as mega-thermal and super humid, with no well defined dry season; excess of rainfall in summer; and climate Af according to the Köppen system of classification (Funari et al., 1987). The annual mean temperature was $22.4{ }^{\circ} \mathrm{C}$, with maximum of $30.4{ }^{\circ} \mathrm{C}$ (hottest month, February) and minimum of $12.6^{\circ} \mathrm{C}$ (coldest month, July). The mean annual rainfall was $2,261 \mathrm{~mm}$, with no water deficit (DAAE/SP). The soil of the parcel had been classified, following Embrapa's nomenclature (1999), as hydromorphic spodosols, quartzarenic neosols and organosols, variations being observed in relation to the depth of the eluvial horizon, that condition different levels of soil moisture (Gomes et al., 2007).

Five sampling points at least $20 \mathrm{~m}$ apart from each other were distributed in each of the following environments, recognised according to their light fluctuation (understorey and gap) and near-surface apparent soil moisture ("dry", and "moist"): "dry understorey" (DU); "moist understorey" (MU); "dry gap" (DG); and "moist gap" (MG). Canopy openings over $4 \mathrm{~m}^{2}$ were considered as gaps. The environments are described in detail by Pires (2006). Irradiance (PAR at soil surface level), was estimated in each point (three measurements per point) for clear days between 10:30 AM and 02:00 PM with a LI 1000 (LiCOR) radiometer, in February 2005. The mean irradiance $\left(x \pm S E, \mu m o l . \mathrm{m}^{-2} / \mathrm{s}\right)$ recorded in DU, MU, DG and MG environments was $43( \pm 15), 13( \pm 3)$, $561( \pm 99)$ and $324( \pm 123)$, respectively. The soil surface moisture $(0-5 \mathrm{~cm})$ was estimated at the time of the assays in each point by the gravimetric method, and maximum and minimum temperature measurements were taken at two points in each of the sampled environments (Figure 1a, b and c).

In the beginning of December, 2003, four samples of 20 seeds each were put into $1 \mathrm{~mm}^{2}$ nylon mesh bags $(12 \times 12 \mathrm{~cm})$, filled with forest soil, distributed on the soil surface, and the number of germinated seeds was recorded monthly.

Germinability data were analysed with Anova, followed by mean comparison ( $\mathrm{F}$ test). The non parametric 
Kruskall-Wallis test was applied if variances were not homogeneous and the respective confidence intervals were calculated (Zar, 1996).

\section{Results}

Ocotea pulchella seeds used in the assays weighed (mean fresh matter mass) $80 \mathrm{mg}$ per seed, and seed water content represented $39 \%$ of that mass. The seeds lost $30 \%$ of their water content after 30 days of storage
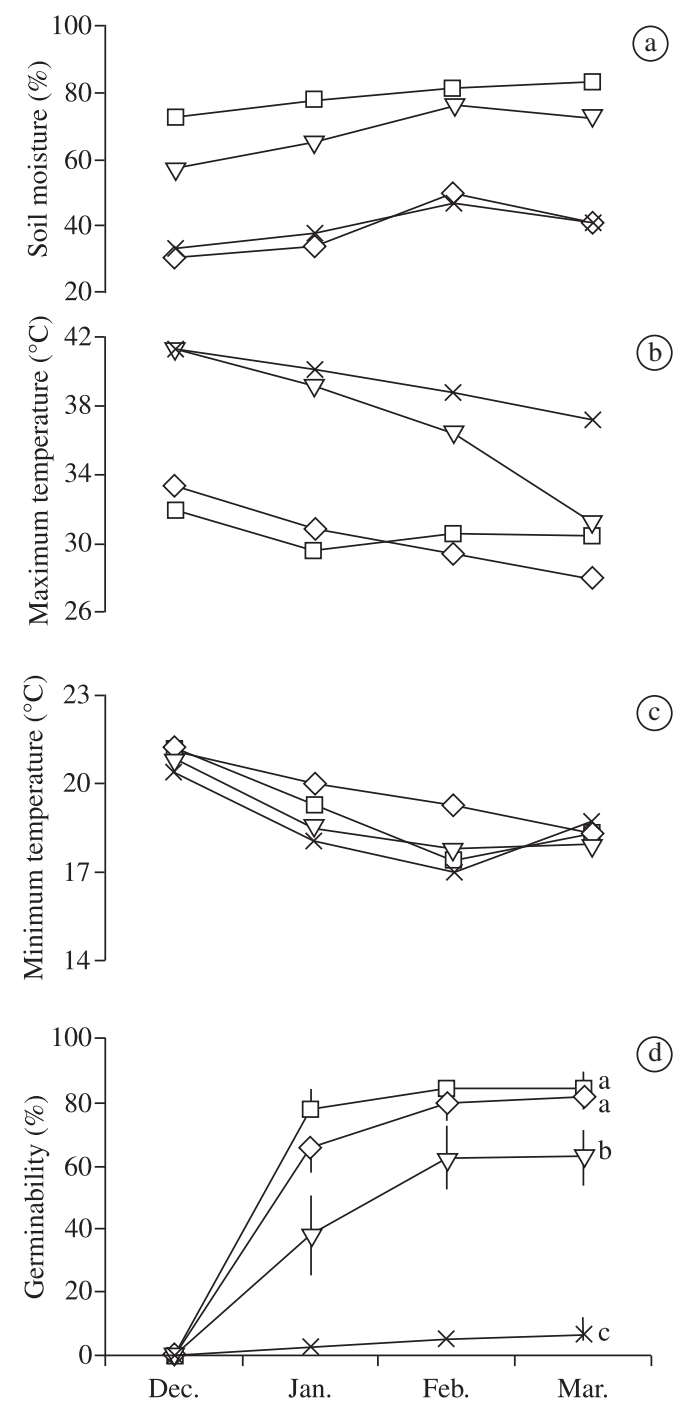

Figure 1. Estimative soil surface $(0-5 \mathrm{~cm})$ a) humidity and b) maximum and c) minimum temperature from December 2003 to March 2004 in environments "dry understorey" $(\diamond)$, "moist understorey" ( $\square)$, "dry gap" (*) and "moist gap" $(\Delta)$ within a permanent parcel in Restinga forest of Parque Estadual da Ilha do Cardoso, Cananéia, São Paulo. d) Germination of $O$. pulchella seeds sowed on the Restinga soil in the different environments is shown. Points represent mean $\pm \operatorname{SE}(n=20)$. Letters compare final germination (LSDTuckey, $\alpha=0.05$ ). in a climatised room with a temperature of $25 \pm 2{ }^{\circ} \mathrm{C}$, and $48 \%$ of water after 60 days of storage, whereas the germinability taken as $100 \%$ at time zero decreased to $49 \%$ and $32 \%$, respectively. The fresh mass of seeds immersed for five days in distilled water at room temperature increased 3-4\% as compared to non imbibed seeds. In the laboratory assays the radicle protrusion at $25^{\circ} \mathrm{C}$ started 7-10 days after sowing. The mean germinability of $O$. pulchella seeds in the laboratory assays was not more than $52 \%$. Most of the remaining non germinated seeds were soft and/or swollen with fungal infestation. The germination of $O$. pulchella seeds under broad band far red light, both under full irradiance and Sombrite ${ }^{\circledR}$ $50 \%$, was statistically similar to germination under white light and darkness (Figure 2). The germinability of flooded seeds at $25{ }^{\circ} \mathrm{C}$ dropped to approximately $5 \%$ after four months from sowing, and similar results were obtained with intact fruits germinated on substrate kept saturated with distilled water (Figure 2).

The temperature dependence of the Ocotea pulchella seed germination rate and germinability are shown (Figure 3). In general, the germinabilities (maximum germination percentage) of different thermal treatments were statistically similar in the range of 16 to $35^{\circ} \mathrm{C}$, with the exception of the temperatures 20 and $35^{\circ} \mathrm{C}$ that differ from each other (Figure 3a). Germination was null at $40{ }^{\circ} \mathrm{C}$. The germination curves (accumulated distribution of the times required for germination) were fitted by the Weibull distribution function. The fitted curves were used to find the time $(\mathrm{t})$ required for the germination of different percentage fractions, and the germination rate

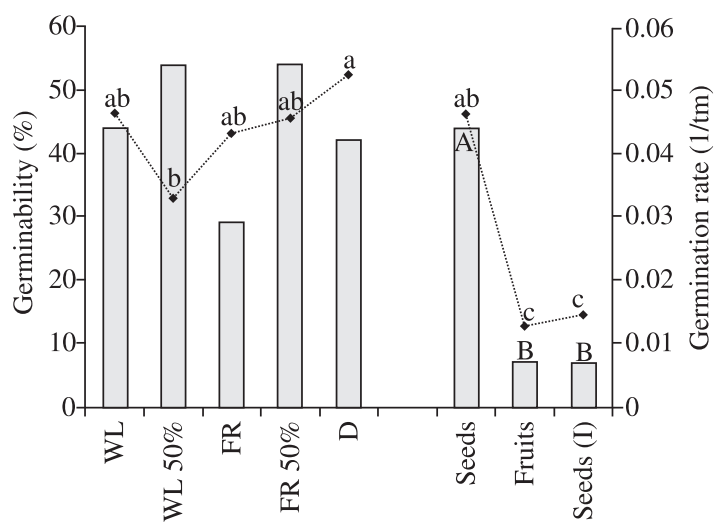

Figure 2. Germinability (bars) and germination rate (dashed lines) of Ocotea pulchella seeds at $25^{\circ} \mathrm{C}$ under white light full irradiance (WL); white light, $50 \%$ of the irradiance (WL 50\%); far-red full irradiance (FR); far-red light 50\% of the irradiance (FR 50\%); and darkness (D). Final germination of naked seeds (seeds); intact fruits (fruits); and naked seeds immersed in water (seeds I) are shown. Capital letters compare germinability (LSDTuckey, $\alpha=0.05, \mathrm{n}=20$ ); small letters compare germination rate (Mann-Whitney test, $\alpha=0.05)$. Germinability did not differ amongst light regimes after 120 days ( $F$ test, $\alpha=0.05, \mathrm{n}=20$ ). 
(reciprocal of $\mathrm{t}$ ) was estimated for different fractions of the population (Figure $3 \mathrm{~b}$ ). At $35{ }^{\circ} \mathrm{C}$, the germinability was below $30 \%$, thus the times taken for germination to reach 30 and $80 \%$ were not calculated. The relationship between the rate of progress of seed germination to $5,10,20,30$ and $40 \%$ and constant temperatures from 16 to $20{ }^{\circ} \mathrm{C}$ exhibits a linear tendency. The germination rate increases with temperatures in the range of 16 to $20{ }^{\circ} \mathrm{C}$, considered as "infra-optimum", and it drops at $35{ }^{\circ} \mathrm{C}$ (Figure $3 \mathrm{~b}$ ). In spite of the insufficient number of points, we also assumed a linear relationship between germination rate and temperature in the "supra-optimum range" (32 to $40{ }^{\circ} \mathrm{C}$ ). Those assumptions allowed the germination response of $O$. pulchella seeds both in the infra and supra optimal temperature range to be investigated in terms of thermal-time model. Figure 4 shows the observed (symbols) and predicted (solid curve) cumulative germination percentage on a thermal-time scale $\left({ }^{\circ} \mathrm{C}\right.$ day) at the temperatures of 16,18 and $20{ }^{\circ} \mathrm{C}$. The line is the cumulative normal distribution of germination, according to the equation $[\mathrm{y}=5+(\mathrm{x} / \sigma)-(\mu / \sigma)]$ whose parameters $\sigma$ (standard deviation) and $\mu$ (median) were found by the linear regression of probit(g) against $\left[\left(\mathrm{T}-\mathrm{T}_{\mathrm{b}}\right) \mathrm{t}_{\mathrm{g}}\right]$ (thermal time). The thermal time $\left(\theta_{\mathrm{g}}\right)$ values corresponding to each observed germination percentage at time $\mathrm{t}_{\mathrm{g}}$ (symbols in Figure 4 ) were determined from
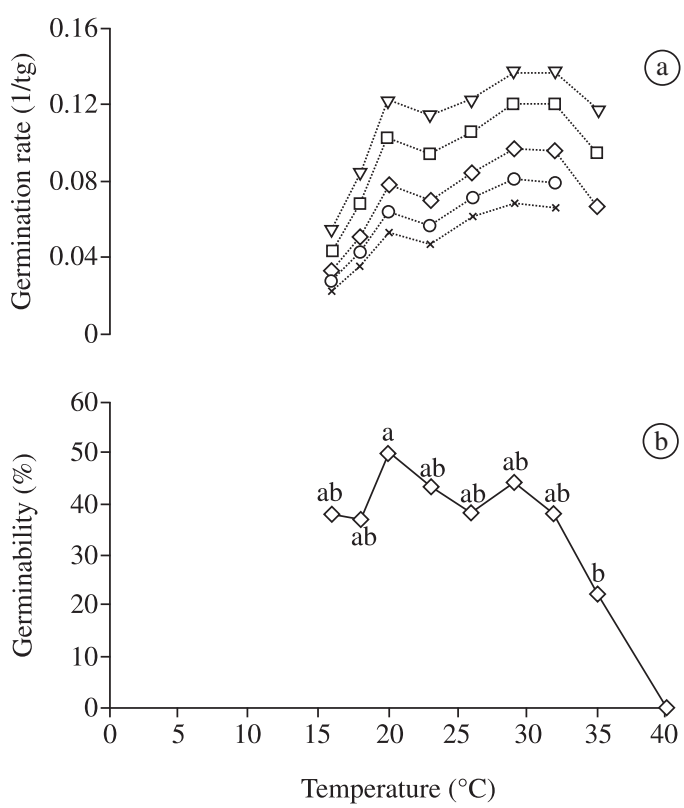

Figure 3. a) Temperature dependence of the germination rate taken as the reciprocal of the time (days) for germination of a given per cent fraction of Ocotea pulchella seeds for different cumulative germination fractions: $5 \%(\Delta) ; 10 \%$ $(\square) ; 20 \%(\diamond) ; 30 \%(0)$; and $40 \%(*)$. b) Temperature dependence on the germinability of Ocotea pulchella seeds after 104 days, under constant temperature regimes of 16 , $18,20,23,26,29,32,35$ and $40{ }^{\circ} \mathrm{C}$. Small letters compare germinability (LSDTuckey, $\alpha=0.05, \mathrm{n}=20$ ). the equation $\theta_{\mathrm{g}}=\left(\mathrm{T}-\mathrm{T}_{\mathrm{b}}\right) \mathrm{t}_{\mathrm{g}}$, with the base temperature, $\mathrm{T}_{\mathrm{b}}$, set at $11.1^{\circ} \mathrm{C}$.

In the field assay carried out in Restinga, the germination of Ocotea pulchella seeds directly sowed on the soil in December occurred over a three-month period from sowing, particularly in the first month (Figure 1d). The germinabilites in "moist" and "dry" understorey were similar to each other and significantly higher than in gaps (Figure 1d). Very low germination (around 10\%) was recorded in "dry gap" environment as compared with the germinabilities observed at other sites (Figure 1d). It is remarkable that the mean germinabilities (around $80 \%$ ) in the field were higher than the germinabilities in the laboratory assays, the mean values of which attained a maximum of $54 \%$.

\section{Discussion}

Ocotea pulchella seeds do not present dormancy and the germination occurs up to approximately two months from dispersion; thus the species can not form a persistent soil seed bank (viable seeds in the soil more than one year) (Alvarez-Buylla and Martinez-Ramos, 1990), suggesting that regeneration is mainly dependent on seed rain (Pires, 2006). Nevertheless, the seeds remain viable up to three months after sowing and that trait can influence the distribution pattern of the germination times, spreading germination over a more extended period and avoiding unfavorable weather for subsequent plant establishment. The $O$. pulchella seeds are lipid rich and the water content is relatively high in mature seeds (Passos and Oliveira, 2003), which can account for their low imbibition rate. It was observed that a decrease of the germinability of $O$. pulchella seeds stored in laboratory conditions (dry storage) was accompanied by a decrease of the moisture percentage of seeds, suggesting that a loss of viability can be related to a decrease in water content of the seed and that seeds exhibit a recalcitrant pattern under storage. Many non-pioneer species from tropical forests evolved in an environment in which water is not a limiting factor, thus their seeds did not suffer selective

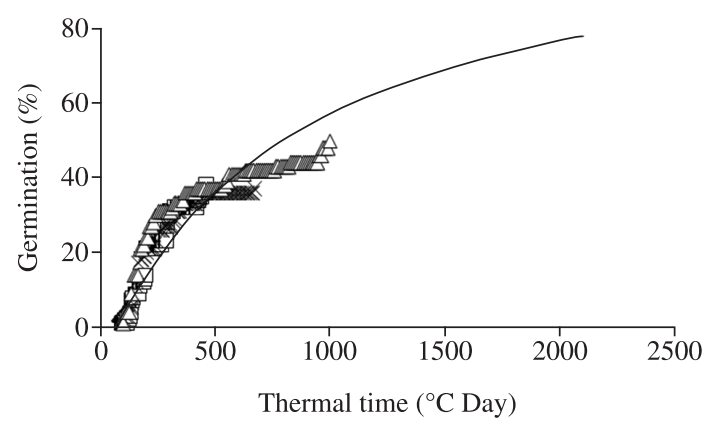

Figure 4. Germination time-courses of Ocotea pulchella seeds at the $16{ }^{\circ} \mathrm{C}(\square) ; 18{ }^{\circ} \mathrm{C}(\times) ; 20{ }^{\circ} \mathrm{C}(\Delta)$ on thermal time scale $\left({ }^{\circ} \mathrm{C}\right.$ day $)$. The line $[\mathrm{y}=5+(\mathrm{x} / \sigma)-(\mu / \sigma)]$ is based upon the parameters $\sigma=3.6$ and $\mu=785.3$ found after fitting the thermal time model at sub-optimal temperatures. 
pressure toward a high tolerance to drying and are recalcitrant (Pammenter and Berjak, 2000).

Taking into account the response of the $O$. pulchella seeds to different light regimes in laboratory conditions, the species appears to demonstrate a wide spectrum in germination response to the light environment and they can be classified as non-photoblastic (Majerowicz and Peres, 2004), since germination is not affected by light quality and quantity. Thus, the seeds can germinate under a wide range of light conditions in the natural environment as observed in the field assays (mainly in the understorey). Such a pattern differs from that observed in some pioneer species in which germination is inhibited by far-red light (Válio and Joly, 1979; Zaia and Takaki, 1998), and it may be advantageous for tropical trees of more advanced successional stages or from the understorey, in which both irradiance and the red:far-red ratio are usually low (Vazquez-Yanes, 1976; Vazquez-Yanes and Orózco-Segovia, 1984). Depending on the temperature, germination can even be favored by far-red light as reported for Ocotea catharinensis, a non-pioneer species of Atlantic forest (Silva and Aguiar, 1998).

Ocotea pulchella seeds germinate over a relatively wide temperature range, although the germination was null at $40{ }^{\circ} \mathrm{C}$. The results suggest low tolerance of the seeds to high temperatures and it can help to explain the lower germination of $O$. pulchella seeds in the gaps in which maximum temperatures recorded at the time of the field assays were around $41.5^{\circ} \mathrm{C}$, whereas the maximum temperature recorded in the forest understorey was $32{ }^{\circ} \mathrm{C}$. The inhibitory effect of high temperatures on seed germination has been observed in many tropical trees (Silva et al., 2002; Godoi and Takaki, 2004). The laboratory assays on the thermal dependence of the germination rate of $O$. pulchella seeds showed that the minimum or base temperature for germination was $11{ }^{\circ} \mathrm{C}$, that is, the seeds are not capable of germinating at that temperature and lower ones (Bradford, 1995). It has been suggested that the optimum temperature for the germination of a given species corresponds to an adaptation of the species to its habitat as well as to its seed dispersion and seedling establishment period (Vázquez-Yanes, 1976). The temperature range in which both the germinability and germination rate of $O$. pulchella seeds presented the highest values was 20 to $32^{\circ} \mathrm{C}$, which is encountered in Cerrado and coastal plain forest (Souza and Lorenzi, 2005) in the seed dispersal period, which occurs preferably in SpringSummer in Restinga forests (Pires, 2006).

Plants, as well as any living organism, require a certain quantity of heat to develop from one stage in their life cycles to another. This measure of accumulated heat is known as physiological time or thermal time, which provides a common reference for the development of organisms. Thermal time $(\theta)$ is often expressed in units called degree-days $\left({ }^{\circ} \mathrm{C}\right.$ day). In the case of seed germination, $\theta$ characterises the linear relation between temperature and the germination rate (Washitani, 1985) under different thermal regimes. The cumulative distribution of

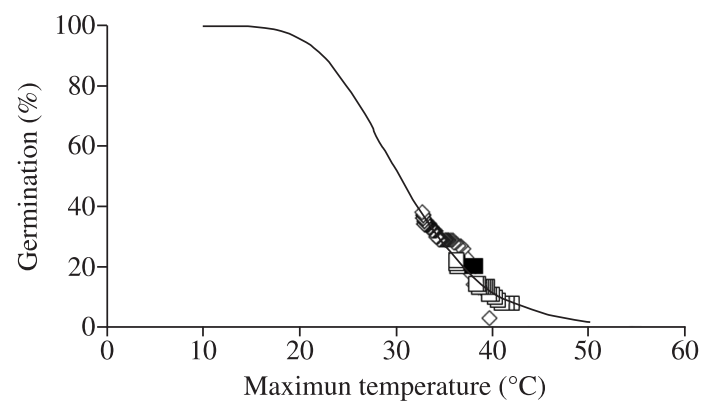

Figure 5. Variation in maximum temperature $\left({ }^{\circ} \mathrm{C}\right)$ with cumulative germination (\%) of Ocotea pulchella seeds at the temperatures of $32(\diamond)$ and $35^{\circ} \mathrm{C}(\square)$. The line $[\mathrm{y}=5+(\mathrm{x} / \sigma)$ $(\mu / \sigma)]$ is based upon the parameters $\sigma=3.6$ and $\mu=785.3$ found after fitting the thermal time model at supra-optimal temperatures.

the isothermal germination of Ocotea pulchella seeds in the infra-optimum range on a thermal time scale shows that the progress toward germination in that range is relatively low as compared, for example, to cultivated crops (Covell et al., 1986). In other words, O. pulchella seeds require a high amount of degrees.day (thermal time) to attain a given percentage of germination (radicle protrusion). The comparison between observed germination percentages $(\mathrm{G} \%)$ and thermal time (symbols in Figure 4) and predicted G\% and thermal time (the curve in Figure 4) suggests that the distribution of thermal time within the seed population can exhibit a deviation from the Gaussian, but this was not tested in the present work. In the nominal supra-optimum range it was assumed that thermal time is constant and the variation in maximum temperature $\left(\mathrm{T}_{\max }\right)$ among the seeds accounts for the differences in germination time. The analysis of the response of $O$. pulchella seeds to "supra-optimal" temperatures shows that seeds are sensitive to high temperatures considering the relatively low median $\mathrm{T}_{\max }$ value (the maximum temperature for $50 \%$ of the seeds to germinate) obtained. Unfortunately, the low germinabilities in the thermal gradient block could affect the parameters, thus such values must be taken with caution.

The relatively low soil moisture in DG as well as the higher irradiances (PAR) can account for the lower germinability of Ocotea pulchella seeds in those environments as compared to MG, since the lower the water potential in the medium the lower the water uptake by the seeds (Hubbell and Foster, 1986). The decrease in both soil water potential and air water potential in the gaps can affect mainly the larger seeds with a low area/ volume ratio, since the maintenance of a favourable water balance for germination in such seeds is made difficult (Foster, 1986). These results are in accordance with those observed in a sampling of regeneration in Restinga forest, where it was observed in low density of seedlings ( $<30 \mathrm{~cm}$ of height) in dry gaps compared to that which occurred in moist gaps (Pires, 2006). 
Although the germinability of Ocotea pulchella seeds in laboratory conditions was strongly inhibited under flooding, the seeds responded relatively well to the high soil moisture in the field. Inga sessilis occurs in areas where soil flooding is frequent and its germination is delayed and partially inhibited under hypoxia (Okamoto and Joly, 2000). These authors also reported that nearly $40 \%$ of the seeds maintain their germination capacity under hypoxic conditions. A possible waterlogging tolerance can be considered for the present species since it also occurs in forests subjected to periodic flooding, as well as in areas with well drained soils (Sztutman and Rodrigues, 2002; Silva and Britez, 2005; Teixeira and Rodrigues, 2006). That relative plasticity, that is, the ability of the seeds to germinate in response to environmental fluctuations (soil water), can represent a very important adaptative trait for the occupation of the heterogeneous space temporal micro-habitats in the Restinga forest.

Both the germinability and the germination rate of intact fruits of Ocotea pulchella were reduced as compared to naked seeds, suggesting an inhibitory effect of the pulp as reported to Callophyllum brasiliensis, an abundant tree from Restinga forests subject to flooding (Scarano et al., 1997). A pericarp-imposed dormancy can be an important trait, allowing the seed to survive under submerged conditions and germinate once exposed to air (Scarano et al., 1997). Moreover, the pulp removal by birds or ants (Souza and Lorenzi, 2005; Passos and Oliveira, 2003) can eventually promote germination.

Germinability in the understorey was significantly higher than in laboratory conditions. The temperature fluctuations in the natural environment may not account for such results since the response of the seeds to the alternating pair $20-30{ }^{\circ} \mathrm{C}$ was similar to the constant temperature (data not presented), and the amplitude of thermal fluctuations recorded in the gaps were higher than in the understorey (Pires, 2006). A possible explanation for the better germinability in the field is that the soil microflora can favour seed germination on the forest floor (Cardoso, 2004).

The results presented here show that, although Ocotea pulchella seeds can germinate relatively well over a wide range of light and temperature conditions, varying over the entire range of environmental conditions commonly encountered on the Restinga soil, the germination responses to the environment may not be explained by only one factor but involves the interaction of two or more factors, particularly temperature and soil moisture. Both laboratory and field assays contributed to a better understanding of the role played by the seeds traits and germination process on the ecology and distribution of the species.

Acknowledgements - The authors thankCNPq for the fellowship (LAP) and financial support (Process no: 473005/2003-4); the Programme "Diversidade, Dinâmica e Conservação em Florestas do Estado de São Paulo: 40 ha de Parcelas Permanentes" (Biota/
Fapesp) for support; and Ednilson da Silva, Cláudio Bernardes, Juninho, and Ary, for technical assistance.

\section{References}

ALVAREZ-BUYLLA, ER. and MARTINEZ-RAMOS, M., 1990. Seed bank versus seed rain in the regeneration of a tropical pioneer. Oecologia, vol. 84, no. 3, p. 314-325.

AMARAL-BAROLLI, A. and TAKAKI, M., 2001. Phytochrome controls achene germination in Bidens pilosa L. (Asteraceae) by very low fluence response. Brazilian Archives of Biology and Technology, vol. 44, no. 2, p. 121-124.

BRADFORD, K., 1995. Water relations in seed germination. In KIGEL, J. and GALILI, G. Seed Development and Germination. New York: Marcel Dekker Inc. p. 351-396.

CARDOSO, VJM., 2004. Germinação. In KERBAUY, GB. Fisiologia Vegetal. Rio de Janeiro: Guanabara Koogan. p. $386-408$.

CARRASCO, PG., 2003. Produção de mudas de espécies florestais de restinga, com base em estudos florísticos $e$ fitossociológicos, visando a recuperação de áreas degradadas, em Ilha Comprida/SP. Rio Claro: UNESP. [Tese de Doutorado].

COVELL, S.,ELLIS, RH., ROBERTS,EH. andSUMMERFIELD, RJ., 1986. The influence of temperature on seed germination rate in grain legumes. Journal of Experimental Botany, vol. 37, no. 178 , p. $705-715$.

DENSLOW, JS., 1980. Gap partitioning among tropical rainforest trees. Biotropica, vol. 12, suppl., no. 2, p. 47-55.

DUMUR, D., PILBEAM, CJ. and CRAIGON, J., 1990. Use of the Weibull function to calculate cardinal temperatures in faba bean. Journal of Experimental Botany, vol. 41, no. 232, p. 1423-1430.

ELLIS, RH., COVELL, S., ROBERTS, EH. and SUMMERFIELD, RJ., 1986. The influence of temperature on seed germination rate in grain legumes. II. Intraspecific variation in chickpea (Cicer arietinum L.) at constant temperatures. Journal of Experimental Botany, vol. 17, no. 183, p. 1503-1515.

FOSTER, SA., 1986. On the adaptive value of large seeds for tropical moist Forest trees: a review and synthesis. The Botanical Review, vol. 52, no. 3, p. 260-299.

FUNARI, FL., DEL-VUONO, YS. and SALUM, ST., 1987. Balanço hídrico de duas áreas de Mata Atlântica: Reserva Biológica de Paranapiacaba e Parque Estadual da Ilha do Cardoso. In Anais do VI Congresso da Sociedade Botânica de São Paulo. São Paulo: SBSP. vol. 4, p. 95 -101.

GARCIA-HUIDOBRO, J., MONTEITH, JL. and SQUIRE, GR., 1982. Time, temperature and germination of pearl millet (Pennisetum typhoides) I. Constant temperature. Journal of Experimental Botany, vol. 33, no. 133, p. 288-296.

GODOI, S. and TAKAKI, M., 2004. Effects of light and temperature on seed germination in Cecropia hololeuca Miq. (Cecropiaceae). Brazilian Archives of Biology, vol. 47, no. 2, p. 185-191.

GOMES, BZ., MARTINS, FR. and TAMASHIRO, JY., 2004. Estrutura do cerradão e da transição entre cerradão e floresta paludícola num fragmento da International Paper do Brasil. Revista Brasileira de Botânica, vol. 27, no. 2, p. 249-262.

GOMES, FH., VIDAL-TORRADO, P., MACÍAS, F., GHERARDI, B. and PÉREZ, JLO., 2007. Solos sob vegetação de restinga na Ilha do Cardoso (SP). I - Caracterização e 
Classificação. Revista Brasileira de Ciência do Solo, vol. 31, no. 6, p. 1563-1580.

HUBBELL, SP. and FOSTER, RB., 1986. Canopy gaps and the dynamics of a Neotropical Forest. In CRAWLEY, MJ. Plant Ecology. Oxford: Blackwell Scientific Publications. p. 77-96.

JOLY, CA., 1991. Flooding tolerance in tropical trees. In JACKSON, MB., DAVIES, DD. and LAMBERS, P. Plant life under oxygen deprivation: ecology, physiology and biochemistry. Hague: SPB Academic Publishing. p. 23-34.

LABOURIAU, LG. and AGUDO, M., 1987. On the physiology of seed germination in Salvia hispanica L. I. Temperature effects. Anais da Academia Brasileira de Ciências, vol. 59, no. 1, p. 37-56.

LORENZI, H., 1992. Árvores brasileiras. Nova Odessa: Editora Plantarum, v.1, p. 130.

MAJEROWICZ, N. and PERES, LEP., 2004. Fotomorfogênese em plantas. In KERBAUY, GB. Fisiologia Vegetal. Rio de Janeiro: Editora Guanabara Koogan. p. 421-438.

OKAMOTO, JM. and JOLY, CA., 2000. Ecophysiology and respiratory metabolism during the germination of Inga sessilis (Vell.) Mart. (Mimosaceae) seeds subjected to hypoxia and anoxia. Revista Brasileira de Botânica, vol. 23, no. 1, p. 51-57.

OLIVEIRA, AA. et al. 2006. A Vegetação - Fitossociologia. In: Rodrigues, RR. IV Relatório Científico do Projeto "Diversidade, dinâmica e conservação em florestas do Estado de São Paulo: 40 ha de parcelas permanentes". Piracicaba: Escola Superior de Agricultura "Luiz de Queiroz", USP. Available from: <www.lerf. esalq.usp.br>.

PAMMENTER, NW. and BERJAK, P., 2000. Aspects of recalcitrant seed physiology. Revista Brasileira de Fisiologia Vegetal, vol. 12, Edição especial, p. 56-69.

PASSOS, L. and OLIVEIRA, PS., 2003. Interactions between ants, fruits, and seeds in a Restinga forest in south-eastern Brazil. Journal of Tropical Ecology, vol. 19, no. 3, p. 261-270.

PINHEIRO, F. and BORGHETTI, F., 2003. Light and temperature requeriments for germination of seeds of Aechmea nudicaulis (L.) Griesebachand and Streptocalyx floribundus (Martius Ex Schultes F.) Mez (Bromeliaceae). Acta Botanica Brasilica, vol. 17, no. 1, p. 27-35.

PIRES, LA., 2006. Ecofisiologia de espécies ocorrentes em uma floresta de restinga. Rio Claro: Instituto de Biociências, UNESP. [Tese de Doutorado].

RAICH, JW. and KHOON, GW., 1990. Effect of canopy openings on tree seed germination in a Malayan dipterocarp forest. Journal of Tropical Ecology, vol. 6, no. 2, p. 203-17.

SALIMON, CI. and NEGRELLE, RB., 2001. Natural regeneration in a Quarternary Coastal Plain in the Southern Brazilian Atlantic Rain Forest. Brazilian Archives of Biology, vol. 44, no. 2, p. 155-163

SÃO PAULO. SECRETARIA DO MEIO AMBIENTE, 2001. Resolução SMA, no. 21, de 21 de novembro de 2001. São Paulo.

SCARANO, FR., RIBEIRO, KT., MORAES, LFD. and LIMA, HC., 1997. Plant establishment on flooded and unflooded patches of a freshwater swamp forest in southeastern Brazil. Journal of Tropical Ecology, vol. 14, no. 6, p. 793-803.

SILVA, EMN., 1988. Determinação de umidade. In: PIÑARODRIGUES, FCM. Manual de análise de sementes florestais. Campinas: Fundação Cargill.
SILVA, A. and AGUIAR, IB., 1998. Germinação de sementes de canela-preta (Ocotea catharinensis) sob diferentes condições de luz e temperatura. Revista Instituto Florestal, vol. 10, no. 1, p. 17-22.

SILVA, SM. and BRITEZ, RM., 2005. A vegetação da planície costeira. In: MARQUES, MCM. and BRITEZ, RM. História natural e conservação da Ilha do Mel. Curitiba: Editora UFPR. p. 49-84.

SILVA, LMM., RODRIGUES, TJD. and AGUIAR, IB., 2002. Efeito da luz e da temperatura na germinação de sementes de Aroeira (Myracrodruon urundeuva Allemão). Revista Arvore, vol. 26, no. 6, p. 691-697.

SOUZA, VC. and LORENZI, H., 2005. Botânica sistemática: guia ilustrado para identificação das famílias de Angiospermas da flora brasileira, baseado em APG II. Nova Odessa : Instituto Plantarum. 640 p.

SUGIYAMA, M., 1998. Estudo de florestas da restinga da Ilha do Cardoso, Cananéia, São Paulo, Brasil. Boletim do Instituto de Botânica, vol. 11, p. 119-159.

SZTUTMAN, M. and RODRIGUES, RR., 2002. O mosaico vegetacional numa área de floresta contínua da planície litorânea, Parque Estadual da Campina do Encantado, Pariquera-Açu, SP. Revista Brasileira de Botânica, vol. 25, no. 2, p. 161-176.

TEIXEIRA, AP. and RODRIGUES, RR., 2006. Análise florística e estrutural do componente arbustivo-arbóreo de uma floresta de galeria no Município de Cristais Paulista, SP, Brasil. Revista Brasileira de Botânica, vol. 20, no. 4, p. 803-813.

VÁLIO, IFM. and JOLY, CA., 1979. Light sensitivity of the seeds on the distribuition of Cecropia glasiovii Snethlage (Moraceae). Zeitschrift für flanzenphysiologie, vol. 91, no. 4, p. 371-376.

VÁZQUEZ-YANES, C., 1976. Estudios sobre la ecofisiologia de la germinación en una zona calido-humeda de México. In: GOMEZ-POMPA, A., GÓMEZ-POMPA, A., VÁZQUEZYANES, C., DEL AMO, S. and BUTANDA, A. Regeneración de Selvas. México: Compañía Editorial Continental. p. 279-387.

VÁZQUEZ-YANES, CR. and OROZCO-SEGOVIA, A., 1984. Ecophysiology of seed germination in the tropical humid tropics of the world: a review. In: MEDINA, E., MOONEY, HA. and VÁZQUEZ-YANES, CR. Physiological ecology of Plants of the Wet Tropics. The Hague: Dr. Junk Publishers. p. 37-50.

1990. Ecological significance of light controlled seed germination in two contrasting tropical habitats. Oecologia, vol. 83, no. 2, p. 171-175.

WASHITANI, I., 1985. Germination-rate dependence on temperature of Geranium carolinianum seeds. Journal of Experimental Botany, vol. 36, no. 163, p. 330-337.

WHITMORE, TC., 1978. Gaps in the forest canopy. In: TOMLINSON, PB., ZIMMERMAN, MH. (Ed.). Tropical Trees as Living Systems. New York: Cambridge University Press. p. 639-655.

ZAIA, JE. and Takaki, M., 1998. Estudo da germinação de sementes de espécies arbóreas pioneiras: Tibouchina pulchra Cogn e Tibouchina granulosa Cogn (Melastomataceae). Acta Botanica Brasilica, vol. 12, no. 3, p. 221-229.

ZAR, JH., 1996. Biostatistical Analysis. 3 ed. New Jersey: Prentice Hall. 662 p. 